ХАРАКТЕРИСТИКА СУЧАСНИХ МУЗИЧНО-КОМП'ЮТЕРНИХ ТЕХНОЛОГІЙ

\title{
THE CHARACTERISTICS OF MODERN MUSIC AND COMPUTER TECHNOLOGIES
}

УДК 781.9

DOI https://doi.org/10.32843/2663-

$6085 / 2020 / 23-2.35$

\section{Ткачов А.С.,}

докт. пед. наук

доцент кафедри початкової

та професійної освіти

Харківського національного

педагогічного університету

імені Г.С. Сковороди

\section{Ван Ціхуей,}

аспірант кафедри загальної педагогіки

і педагогіки вищої школи

Харківського національного

педагогічного університету

імені Г.С. Сковороди у статті визначено, що в останні роки музично-комп'ютерні технології активно використовують у музичній діяльності та в галузі музичної освіти. Ураховуючи їхні значні переваги, учені у своїх працях приділяють увагу висвітленню окремих аспектів проблеми використання цих технологій у музичній та освітній галузях. Установлено, що сьогодні в Україні та КНР не вистачає наукових праць, в яких представлено комплексну характеристику сучасних музичнокомп'ютерних технологій, тому метою статmі є визначення та характеристика сучасних музично-комп'ютерних технологій. Як установлено, однією з таких технологій є звукові редактори, які використовують для запису, обробки й редагування музичного твору, зокрема для копіювання, вирізання, вставки деяких фррагментів твору. Також наведено характеристику таких музично-комп'ютерних технологій, як програми-секвенсори, що дають змогу записувати, редагувати, відтворювати музику за допомогою так званих послідовностей MIDI-даних. Доведено, що в музичній та освітній діяльності доцільно також використовувати нотний редактор, що дає змогу вводити, редагувати та роздруковувати нотний текст різноманітного рівня складності, причому варіативність нотного тексу обмежується лише можливостями програми. Уточнено, що сьогодні популярним редактором нотних партитур $\epsilon$ Cusbase, що здатний до підтримки VSTплагінів. Серед недоліків указаної програми слід назвати неможливість імпортування чи експортування збережених даних між Cusbase ma інших програм багатоканального відтворення. Визначено, що використання вказаних музично-комп'ютерних технологій значно розширює можливості людей у музичній та музично-освітній діяльності. Проте для забезпечення ефективного використання у цих видах діяльності комплексу зазначених технологій необхідно врахову- вати специсрічні характеристики й можливості кожної $з$ них.

Ключові слова: характеристика, музичнокомп'ютерні технології, звуковий редактор, нотний редактор, програма-секвенсор.

It was determined in the article that in recent years music and computer technologies have been actively used in music and music education. Given their significant advantages, scientists pay attention to display some aspects of the problem of using these technologies in music and education in their publications. At the same time, it is established that today in Ukraine and the People's Republic of China there are not enough scientific works that present a complex characteristic of modern music and computer technologies. Therefore, the purpose of the article is to identify these technologies and to describe their characteristics. One of these technologies is audio editors that are used to record, process and edit a music piece, in particular to copy, cut, and paste some pieces of a work. It was also given the features (peculiarity) of music-computer technology, such as sequencer programs that allow you to record, edit, play music using so-called MIDI data sequences. It was proved in the article that it is appropriate to use a music editor in music and educational activity that allows you to enter, edit and print a note text of various complexities, with variability of the note text being limited only by the capabilities of the program. It has been clarified that Cusbase that is capable of supporting VST plugins, is a popular editor of sheet music today. The disadvantages of this program include the inability to import or export stored data between Cusbase and other multichannel programs. It has been identified in the study that the using of these music-computer technologies greatly empowers people in music and music-educational activities. However, to ensure the effective use of these technologies in these activities, it is necessary to consider the specific characteristics and capabilities of each of them. Key words: characteristics, music and computer technologies, sound editor, music editor, sequencer.
Постановка проблеми в загальному вигляді. Наприкінці XX - на початку XXI ст. комп'ютери стали невід'ємним атрибутом профресійної діяльності фрахівців у різних галузях. У цьому плані музикальна сорера не стала винятком, адже динамічний розвиток комп'ютерних технологій дав їм змогу стати важливою часткою музичного устаткування як окремих фрахівців, так і музичних колективів. У світлі цього виникла актуальна потреба в організації підготовки майбутніх фрахівців музичних спеціальностей до використання зазначених технологій у майбутній професійній діяльності.

Водночас на основі аналізу наукової літератури встановлено, що процес комп'ютеризації освіти в Україні, зокрема впровадження музичнокомп'ютерних технологій у систему музичної освіти, характеризується не тільки певними досяг- неннями, а й вагомими недоліками. Зокрема, академік А. Пашков констатує, що внаслідок відсутності єдиної політики розвитку сорера цифррових технологій в Україні розвивається дуже хаотично та окремо від сорери освіти. Це призводить до надзвичайно низького рівня цифрової грамотності педагогів. Також однією з проблем розвитку та інтеграції цисррових технологій в освітній процес учений називає застарілі методики викладання [4, с. 195], тому сьогодні існує необхідність удосконалення музичної освіти на основі широкого використання музично-комп'ютерних технологій.

Аналіз останніх досліджень і публікацій. Як свідчить аналіз наукової літератури, вченими висвітлено окремі аспекти проблеми використання музично-комп'ютерних технологій у професійній діяльності музикантів та музичній освіті. Так, роль 
та місце комп'ютерних технологій у царині музики проаналізовано в працях таких учених, як І. Заболотська, В. Луценко, А. Марков, М. Сова, Чен Жуїн та ін. Можливості застосування комп'ютерних технологій у музичній освіті висвітлено І. Горбуновою, Лю Цин, О. Поляковою, Пен Ченом, Л. Робустовою, Сяньюй Хуаном, Г. Юферовою та ін. Досвід дослідження електронної музики та перспективи іï подальшого розвитку розкрито в дослідженнях Чжу Юнбея, Л. Суслової, П. Трубінова, К. Фадєєвої та ін.

Виділення не вирішених раніше частин загальної проблеми. У дослідженні встановлено, що науковці зробили вагомий внесок у вивчення проблеми використання музично-комп'ютерних технологій у професійній та освітній діяльності. Водночас варто зауважити, що ними висвітлено тільки окремі аспекти зазначеної проблеми. Зокрема, сьогодні в Україні та КНР не вистачає наукових праць, в яких представлено комплексну характеристику сучасних музично-комп'ютерних технологій. Недостатня теоретична й практична розробленість даного аспекту порушеної проблеми зумовила вибір теми статті.

Мета статті. Метою роботи є визначення сучасних музично-комп'ютерних технологій та наведення їх характеристик.

Виклад основного матеріалу. За результатами аналізу наукової літератури встановлено, що комп'ютерні технології використовуються в музичній сорері 3 кінця XX ст. Найбільш рання комп'ютерна музика створювалася за допомогою електронних компонентів, де застосовувалися коливальні схеми для генерування різних фрорм хвиль, які підсилювалися для фрормування звуків, а зміни форми хвилі створювали різний тембр. Однак електронна музика в той період ще залишалася на експериментальній фразі створення.

3 початку XXI ст. спостерігається інтенсивний розвиток і використання музично-комп'ютерних технологій. При цьому за останні десять років розвиток комп'ютерної музики переважно супроводжувався розвитком мультимедіа. Інтеграція в єдине ціле цисрової аудіотехніки персонального комп'ютера і технології MIDI дало змогу сорормувати ефрективну систему для виробництва комп'ютерної музики. При цьому музичнокомп'ютерні технології, поєднуючи в собі дві дуже різні сорері діяльності людини - музичну та технологічну, дають змогу виконувати різні складні операції під час створення або програвання музичних творів, значно полегшуючи творчий процес музиканта. Крім того, сучасний розвиток музичнокомп'ютерної техніки дає змогу використовувати комп'ютер як засіб редагування, надання додаткових ефректів, зберігання та комбінування різноманітних музичних творів. Отже, ці технології мають широкі можливості. Охарактеризуємо деякі з них.
Так, однією із сучасних музично-комп'ютерних технологій $€$ звукові редактори, або аудіоредактори. Програми цього типу здатні до виконання таких стандартних операцій для обробки музичного твору, як копіювання, вирізання, вставки, заглушки деяких фррагментів твору або їх інвертації. Більш розвинуті програми виконують складні операції зі спектральної, тимчасової та динамічної обробки звукового сигналу. Зокрема, використання звукових редакторів дає змогу записувати, редагувати та обробляти музичні твори, даючи музиканту змогу підібрати оптимальні варіанти звучання. За допомогою звукових редакторів виникає також можливість створювати звукові файли, використовуючи фррагменти 3 музичного твору з подальшим їх компонуванням відповідно до поставленого завдання.

Одним із найкращих багатофуункціональних аудіоредакторів $€$ програма Sound Forge, що містить інструменти й ефекти для створення та редагування музичних даних. Вона здатна виконувати такі фрункції, як запис високоякісного звукового сигналу, візуального відображення сигналу, редагування цифрового звуку, видалення шумів, відновлення старих записів, архівування та конвертування фрайлів, перетворення інформації на популярні веборормати [6, с. 76].

Серед сучасних музично-комп'ютерних технологій слід також відзначити програми-секвенсори, що надають широкі можливості для творчості музикантам та викладачам музики. Секвенсор (англ. Sequencer) являє собою пристрій, призначений для створення та відтворення інформації для електронного музичного інструменту у вигляді MIDI-інформації. Такі типи програм дають змогу записувати, редагувати, відтворювати музику за допомогою так званих послідовностей MIDI-даних. За допомогою цих програм можна не тільки створювати та виконувати музичні твори, а й налаштовувати тембр, динамічність та інші параметри і характеристики звучання музики. Серед недоліків зазначеної технології слід виділити вимогливість до ресурсів комп'ютера та складність у використанні для людей з відсутністю музичної освіти [4, с. 141].

Зокрема, використання таких програм-секвенсорів, як Nuendo чи Cubase, надає можливості музиканту для демонстрації звучання музичного твору у виконанні різноманітних музичних інструментів із додаванням додаткових ефектів, створення й редагування нотного тексту, аранжування мелодії для будь-якого музичного колективу шляхом поєднання секвенсора з графрічним редактором. Cubase, являючи собою серію комп'ютерних програм, дає також змогу змішувати треки та зберігати їх у найпоширеніших аудиофрорматах, таких як wav або mp3 [4, с. 141]. Причому починаючи 3 1996 р. Cusbase здатна до підтримки VST-плагінів, 
що сьогодні $є$ основним стандартом для всіх програм багатоканального відтворення музики. Серед недоліків указаної програми слід назвати неможливість імпортування чи експортування збережених даних між Cusbase та інших програм багатоканального відтворення навіть за наявності однакових стандартів зберігання інфрормації.

Зазначимо, що програма Steinberg Nuendo має можливість працювати з різними аудіоформатами, включаючи фрормат MIDI-даних за допомогою секвенсора. Nuendo на відміну від попередньої програми має більшу кількість фуннцій і може використовуватися не тільки музикантами, а й для озвучення фрільмів, ТВ-програм, радіопередач тощо. Зазначена програма також оснащена певними додатковими функціями, наприклад більшою кількістю сурраунд-каналів, плагінів, покращеним редактором кроссфейдів тощо [7, с. 142].

Серед переваг секвенсорних програм слід також назвати їхню здатність до значного полегшення діяльності музикантів, адже внаслідок можливості попереднього коригування опцій звучання й обробки кожного каналу під час виступу більшість музикальних творів потребує лише незначної корекції, що дає виконавцю змогу не відволікатися на переключання обробки ефектів відтворювання та звучання, а зосередитися тільки на грі [3, с. 82].

Варто зазначити, що існують також інші способи взаємодії комп'ютерних технологій та музики. Так, використання нотного редактора дає змогу вводити, редагувати та роздруковувати нотний текст різноманітного рівня складності - від легкої п'єси до складних оркестрових творів. При цьому варіативність нотного тексу обмежується лише можливостями програми. Найпопулярнішою програмою такого типу $є$ Sibelius, що має можливість працювати як на системі Windows, так і на Mac OS. Програма призначена для використання композиторами, виконавцями, аранжувальниками та викладачами музики.

Також слід приділити увагу нотному редактopy Finale, що має значні можливості для праці 3 новітніми або нестандартними форматами запису. Зокрема, використання такого нотного редактора, як Finale 2003, дає змогу вирішувати завдання щодо створення ритмічних партій та партитур, музикування, створення та систематизації нотного матеріалу [2, с. 16].

Однією із сучасних музично-комп'ютерних технологій $€$ цифровий музичний запис, за якого використовують цифрові магнітофони: DAT-магнітофони, цифрові багатоканальні магнітофони, хард-диск-рекордери та робочі станції. Для роботи з вищевказаним обладнанням комп'ютер має бути оснащений спеціальним обладнанням для відтворення та запису звуку. Найбільш розповсюдженим таким обладнанням є додаткові зву- кові карти, що оснащені аналого-цифровим входом для запису звуку та цифрово-аналоговим для його відтворення.

Широкі можливості для обробки музичного твору та манери його звучання надають також еквалайзери. За їх допомогою можна здійснювати не тільки монтаж музичного втору, а й задавати обробку сигналу на виході. Ще однією можливістю, якою володіють музично-комп'ютерні технології, $€$ здатність зберігати на жорсткому диску банки звукових програм із внутрішньої пам'яті синтезаторів. Такі програми мають назву «редактор» або «бібліотекар» та дають змогу не лише редагувати записані патчі, а й комбінувати їх між собою [9].

Існують також програми для здійснення MIDI-акомпанементу, що призначені для аранжування виступів інструментальних груп. Відтворення аранжування мелодії здійснюється за допомогою мультимембральної аудіокарти, синтезатора або звукового модуля. Такі програми містять у собі кліше всіх найпоширеніших стилів музики. Деякі з таких програм мають можливість створити власний стиль, редагувати існуючий та накладати додаткові треки поверх акомпанементу.

Віртуальні синтезатори дають змогу імітувати роботу звичайних синтезаторів, але мають порівняно $з$ ними більш розширені можливості. Вони дають змогу створювати незвичні звуки та шуми, а також здійснювати плавне перетворення одного звуку на інший. Серед програм подібного типу слід виділити Meta Synth та Turbo Synth, що призначені для роботи на системах Macintosh, а також Generator та Reality, що призначені для операційної системи Windows. Окремо слід виділити програми Re Birth, Groove Maker, які, по суті, є ритмбоксами 3 меншою кількістю опцій порівняно 3 повноцінними синтезаторами [5; 8].

Окремої уваги заслуговують програми-плеєри, серед яких слід виділити такі: Winamp - мультимедійний плеєр зі здатністю підтримувати майже всі існуючи формати; NAD, здатний до виконання всіх основних фрункцій; K-Jofol, спроможний до повної перебудови програмного інтерфейсу $[1 ; 5]$.

Висновки. На підставі викладеного зроблено висновок про те, що використання музичнокомп'ютерних технологій значно розширює можливості людей у різних видах музичної діяльності, виводячи музичну галузь на якісно новий рівень. Зокрема, профресійним музикантам та педагогам ці технології значно полегшують процес створення музичних композицій, а також надають додаткові можливості для їх виконання завдяки здатності створювати додаткові ефекти під час програвання та змінювати характер звучання. Музичнокомп'ютерні технології надають доступ до світу музики навіть тим людям, які не мають музичної освіти, даючи їм змогу створювати власні музичні композиції та переробляти існуючі. Водночас 
варто зазначити, що для забезпечення ефективного використання комплексу наведених технологій у музичній та освітній діяльності необхідно враховувати специфрічні характеристики й можливості кожної $з$ них.

Викладений у статті матеріал не вичерпує всіх аспектів проблеми використання фрахівцями музично-комп'ютерних технологій. У подальших дослідженнях планується визначити й обґрунтувати педагогічні умови, що забезпечують ефективність використання зазначених технологій у професійній підготовці майбутніх музикантів у вищій школі КНР та України.

\section{БІБЛІОГРАФІЧНИЙ СПИСОК:}

1. Qin Y., Yang J.T. Impact of Computer Music Technology on the Effect of the Information Memory of Audiences International Conference on Power Electronics and Energy Engineering (PEEE 2015). URL : http://citeseerx.ist.psu.edu/viewdoc/download?do $\mathrm{i}=10.1 \cdot 1.1034 .2141 \&$ rep=rep1\&type=pdf.

2. Живякин П.Л. Электромузыкальные инструменты. Праобразы и предшественники. Музыка и электроника. 2004. № 1. С. 16-17.

3. Луценко В. Музично-комп'ютерні технології у просресійній діяльності майбутнього вчителя музики. Молодь і ринок. 2011. № 7. С. 81-84.
4. Пашков А. Інклюзія та цифррові технології в освіті як сучасні методи змішаного навчання для людей з особливими потребами. Формування публічної служби, чутливої до людей з особливими потребами: цифрові технології : матер. наук.-практ. конфр. за міжнар. участю. Київ, 2017. С. 194-198.

5. Сова М.О. Музичні комп'ютерні технології як інструментарій сучасного освітнього процесу. Hayковий часопис НПУ імені М.П. Драгоманова. Серія 16. Творча особистість учителя: проблеми теорії і практики. 2012. Вип. 16(26). с. 128-132.

6. Фишер Д.П. Создание и обработка звука в Sound Forge / пер. с англ. С.В. Корсакова. Москва, 2005. 136 c.

7. Цимбал К.О., Цимбал С.В. Використання програм секвенсорів та графрічних редакторів у навчальному процесі. Конкурентоспроможність вищої освіти України в умовах інфрормаційного суспільства : збір. тез I Міжнар. наук.-практ. конф., м. Чернігів, 9 листопада 2018 р. Чернігів, 2018. С. 141-142. URL : http://elibrary.kubg.edu.ua/id/eprint/25283/1/S Tsymbal Mkonf 2018 IM.pdf.

8. 有哪些需要计算机技术，又和音乐相关的职 业? URL : https://www.zhihu.com/question/38317546/ answer/76023337

9. 计算机音乐（计算机技术和音乐艺术相融合的 音乐)。URL： https://baike.baidu.com/item/计算机音 乐/5195551. 